\title{
Szkice
}

\section{Wystarczy mocno i wytrwale zastanawiać się nad jednym życiem... Biografistyka jako hermeneutyczne wyzwanie}

Anna Legeżyńska

TEKSTY DRUGIE 2019, NR 1, S. 13-27

DOI: 10.18318/td.2019.1.2 | ORCID: 0000-0001-7068-3685

$\mathbf{P}$ isanie biografii jest szczególnym doświadczeniem. Sprzyja nawiązaniu specyficznej relacji z osobą opisywaną, ale też pozwala uważniej przyjrzeć się sobie. Kiedy w nieodległym czasie stanęłam przed podobnym wyzwaniem, na zamówienie wydawnicze pisząc książkę o Julii Hartwig', początkowo nie miałam takiego pomieszania myśli i uczuć, jak później. Dopiero gromadząc materiały, pojęłam niewygodę sytuacji zmuszającej do rozstrzygnięcia wielu dylematów technicznych, formalnych i etycznych. Podobnymi wrażeniami dzieli się Andrzej Franaszek w zakończeniu potężnego dzieła poświęconego życiu Zbigniewa Herberta, które w polskiej

1 A. Legeżyńska Julia Hartwig. Wdzięczność, Wydawnictwo UŁ, Łódź 2017. Książka ukazała się nakładem Wydawnictwa Uniwersytetu Łódzkiego, które zainicjowało ciekawą serię pod nazwą "Literatura i egzystencja". Poetyka tytułów obejmuje hasło uznane za kluczowe dla danej twórczości i nazwisko pisarza lub poety. Kolejno w serii wydane zostały prace: A. Kałowska Witkacy. Etyka, M. Woźniak-Łabieniec Jarosław Marek Rymkiewicz. Metafizyka, M. Urbanowski Brzozowski i ostatnio T. Garbol Miłosz.
Anna Legeżyńska prof. dr hab., pracuje w Instytucie Filologii Polskiej Uniwersytetu im. Adama Mickiewicza w Poznaniu, wykłada historię literatury XXi XXI wieku. Zajmuje się głównie poezją, ostatnio opublikowała monografie: Od kochanki do psalmistki... Sylwetki, tematy i konwencje liryki kobiecej (2009) oraz Julia Hartwig. Wdzięczność (2017). Kontakt: Anna.Legezynska@amu.edu.pl 
biografistyce chyba nie ma sobie równych. Książka liczy niemal półtora tysiąca stron, zawiera mnóstwo cennych informacji wydobytych ze źródeł archiwalnych i odsłania o wiele bardziej skomplikowany portret poety niż ten, który ukazują kanoniczne opracowania. Na ostatnich kartach drugiego tomu czytamy:

Pisanie biografii jest długą podróżą. Nie ma potrzeby jej mitologizować, biograf jest rzemieślnikiem, a nie natchnionym artystą, czego czasem chcą od niego co bardziej egzaltowani czytelnicy, pytający na spotkaniach autorskich, jak to jest „żyć cudzym życiem”, nieledwie - „wcielać się" w swojego bohatera. Nie wcielamy się, chyba jednak nie tracimy własnego życia, tak naprawdę główną częścią tej drogi - wymagającej cierpliwości, lepiej zresztą, by nie odbywała się zbyt szybko - są godziny wertowania katalogów, zamawiania archiwalnych teczek, przeglądania indeksów w dziennikach i tomach korespondencji, czytania, czytania, robienia notatek. [...]

Choć przecież dzieje się też coś więcej, wpływają na nas cudze opowieści, czasem wzruszające, jak wtedy gdy kilka listów poznawanych w ciągu godziny przynosi esencję czyjegoś życiorysu [...]

Nic prostszego, niż powiedzieć, że biografia powinna być uczciwa. W praktyce to oznacza tysiące drobnych decyzji: w którym momencie urwać cytat, co schować za nawiasem z trzema kropkami, jaki kontekst dopowiedzieć, jak rozstawić akcenty, co jednak, mimo wszystko, pominąć. Kusi nas też władza narratora czy przynajmniej siła opowieści, raz

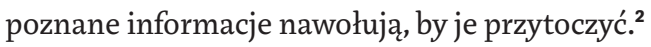

Cytuję długi fragment autotematycznej refleksji Andrzeja Franaszka dlatego, że wyjątkowo trafnie i uczciwie charakteryzuje on sytuację hermeneutyczna, w jakiej znajduje się biograf. Mowa tu o relacji między Ja - Inny, o konieczności rozpoznania cudzej osobowości i scenariusza przytrafiającego się jej losu. Nazwanie pracy biografa rzemiosłem też wydaje się słuszne, choć można dalej dyskutować o pokusach narratywizmu (co łączy się z gatunkowymi odmianami biografii). Uprawianie biografistyki da się porównać z innym rodzajem żmudnej i pozornie nietwórczej pracy, która jednak

2 A. Franaszek Postscriptum, w: Herbert. Biografia, t. 2, Pan Cogito, Znak, Kraków 2018, s. 381 (podkr. - A.L.). 
okazuje się fascynująca, choć najeżona licznymi trudnościami (dokonywania wyborów). Myślę o przekładzie literatury, nie bez kozery nazywanym „sztuką". Sztuka translacji i sztuka biografii mają wspólny mianownik: rozumienie. Tłumaczenie przynosi nową (innojęzyczną) postać oryginalnego dzieła, biografia także jest wariantywna i nigdy ostateczna. „Tłumaczenie”, czyli opowiedzenie cudzego życia, pociąga za sobą liczne konsekwencje; jedną z ważniejszych zdaje się wybór dominanty, czyli zasady organizującej (literackie lub faktograficzne) tworzywo, która z kolei jest efektem interpretacji. Nie roztrząsając dalej kwestii, czy interpretacja ma być odkrywaniem (utajonego w dziele), czy też wynajdywaniem (konstruowaniem) sensu, przyjmijmy tyle, że zarówno tłumacz, jak i biograf - rzecz jasna, w modelowym opisie - podejmują obowiązki twórcze. I biorą też na siebie autorską odpowiedzialność, potwierdzając ten fakt własnym nazwiskiem na tytułowej stronie, umieszczonym w drugiej kolejności za nazwiskiem autora oryginału czy bohatera biografii. Chodzi o odpowiedzialność za wcielenie opisywanej postaci, której utekstowiony los za sprawą intencji biograficznej przechodzi w czas długiego trwania, ogołocony i dostępny kolejnym pokoleniom jedynie tak, jak pisał Czesław Miłosz:

\section{$[\ldots]$}

Nic ponadto powiedzieć nie można. Żył, kiedyś,

Na stronicach kronik, w innym wietrze,

Pod inną koniunkcją gwiazd, choć na tej samej

Ziemi, która, jak mówią, jest boginią. ${ }^{3}$

Opisywanie cudzego życia jest czymś innym niż praktykowanie autobiografii ${ }^{4}$. Przesunięcie uwagi z Ja na Ty pociąga za sobą wiele oczywistych konsekwencji formalnych, lecz przede wszystkim tworzy zupełnie odmienną sytuację epistemiczną. Używając pojęcia biografistyki, zamierzam w tym miejscu rozważyć kilka aspektów biografii rozumianej jako tekst, możliwy do realizacji w różnych odmianach gatunkowych oraz zanotować kilka uwag odnoszących się do sytuacji pisania o cudzym (twórczym) życiu. Nawiązując do znanej koncepcji Małgorzaty Czermińskiej, która scharakteryzowała trzy

Cz. Miłosz Wcielony, w: Dalsze okolice, Znak, Kraków 1991, s. 13.

4 Formuła pożyczona z książki Jerzego Madejskiego Praktykowanie autobiografii. Przyczynki do literatury dokumentu osobistego i biografistyki, Wydawnictwo Naukowe Uniwersytetu Szczecińskiego, Szczecin 2017. 
aspekty autobiografii ${ }^{5}$ pojmowanej jako świadectwo, wyznanie i wyzwanie, chciałabym to ostatnie miano nadać opisywaniu czyjegoś życia, podjętemu z intencją utrwalenia (w postaci zapisu dokumentarnego lub/i narracyjnego). Zapowiedziane w tytule odniesienie do hermeneutyki będzie tutaj stosunkowo swobodne, nie chodzi bowiem o rozważenie problemu w kontekście filozoficznym, lecz raczej literaturoznawczym (krytycznoliterackim).

\section{1.}

Niemal pół wieku minęło już od czasu, gdy strukturaliści rozprawili się z pokutującym na obrzeżach ówczesnego literaturoznawstwa duchem tradycyjnego biografizmu, zamykanego w XIX-wiecznej formule „życia i twórczości”. Duch ten pokutował jeszcze w pracach Juliusza Kleinera ${ }^{6}$ i jego późniejszych naśladowców, a pochodził z romantyczno-pozytywistycznej spuścizny genetyzmu. Konsekwencją przełomu antypozytywistycznego stało się nowe ujmowanie związku autora z dziełem i stopniowe oddzielanie życia od literatury. Spektakularny sukces metodologiczny formalistów polegał na tym, że udało im się na długi czas wyeliminować z literaturoznawczych dociekań zainteresowanie osobowością autora. W rezultacie jeszcze strukturaliści dokonywali karkołomnych odcieleśnień „podmiotu czynności twórczych”, byle tylko utrzymać twardą doktrynę autonomii tekstu literackiego.

W 1975 roku ukazał się pokonferencyjny tom zatytułowany Biografia-geografia - kultura literacka, który rozpoczynał się tekstem jednego z dwóch głównych redaktorów, Janusza Sławińskiego, Myśli na temat: biografia pisarza jako jednostka procesu historycznoliterackiego. „Biografizm nie jest już dziś odczuwany ani jako zagrożenie, ani jako szansa"7 , oceniał autor. Jednocześnie przypominał, że jednak radykalny antybiografizm w teoriach rosyjskich formalistów został następnie złagodzony przez Jana Mukařovskiego, upominającego się o uwzględnienie podmiotowego aspektu literatury. Biografia twórcy, zdaniem czeskiego badacza, nieuchronnie splata się z innymi formami jego aktywności

5 M. Czermińska Autobiograficzny trójkq̨t. Świadectwo, wyznanie i wyzwanie, Universitas, Kraków 2002.

6 Z. Matracki Biografistyka literacka Kleinera, w: Biografia - geografia - kultura literacka, seria: Z dziejów form artystycznych, tom XL, red. J. Ziomek, J. Sławiński, Ossolineum, Wrocław 1975, S. $139-169$.

7 J. Sławiński Myśli na temat: biografia pisarza jako jednostka procesu historycznoliterackiego, w: Biografia-geografia-kultura literacka, s. 9. 
życiowej. Także Janusz Sławiński nie negował tej zależności, ale szukał sposobu, by opisać biografię jako jednostkę porównywalną z pozostałymi elementami procesu historycznoliterackiego. Najpierw rozpoznawał krajobraz po bitwie, czy raczej długotrwałej batalii (o autonomię literatury), wskutek której biografistyka oderwała się od historii literatury. Stała się autonomiczną, wyspecjalizowaną działalnością badawczą, zajmującą się gromadzeniem i katalogowaniem faktów. W rezultacie „benedyktyński trud armii biografów, wykuwających [...] swymi nieefektownymi toporkami masywną budowlę, której mieszkańcy mogą się już teraz w ogóle nie liczyć z jurysdykcją historycznoliteracką" ${ }^{\text {, }}$ wydaje się jałowy (w czasie, gdy Sławiński zapisuje swoje Myśli..., czyli w połowie lat 70.). Aby frustrujące dla obu stron - zarówno biografistyki, jak i historii literatury - samopoczucie zmienić, należałoby głęboko zrewidować sens i cel tego rodzaju badań: „dla historyka literatury produktywne jest takie pojmowanie biografii, które umieszcza ją właśnie p o mi ię zy materiałem zdarzeń wypełniających życie twórcy a zbiorem tekstów składających się na jego dorobek pisarski"’.

Badacz charakteryzował owo "pomiędzy” za pomocą szeregu opozycji, rozróżniając realny przebieg biografii od jej „wtórnego modelowania” przez zmieniające się konteksty społeczno-kulturowe, dzięki którym przesuwa się ona z „czasu macierzystego" w „rejestr długiego trwania”. I choć możliwe jest rozróżnienie udokumentowanego przebiegu życia pisarza od legendy biograficznej, to zwykle oba porządki się mieszają; prawda życia pozostaje niedocieczona. Skoro tak, jakie aspekty realnej biografii pisarza powinny interesować historyka literatury? Zdaniem autora Myśli... tylko te, które pozwalają odtworzyć proces „jego sytuowania się w kulturze literackiej danego czasu i środowiska"10.

Z kolei Edward Balcerzan, jako strukturalista równie pewny niezależności literatury wobec życia, w tym samym tomie nazywał biografię „,ęzykiem" i (jak gdyby niepomny kapryśnej przypadkowości losu...) dowodził, że pisarz świadomie tworzy z niej „tekst”, semiotyczny przekaz dla współczesnych lub potomności"1. Zarówno Sławiński, jak i Balcerzan w rozważaniach o biografii wykorzystywali żelazny zestaw pojęć strukturalizmu: opozycję diachronii

8 Tamże, s. 10.

Tamże, s. 15 (wyróż. autora).

Tamże, s. 22.

11

E. Balcerzan Biografia jako język, w: Biografia-geografia..., s. 26-27. 
i synchronii, langue i parole, systemu i tekstu. Natomiast Erazm Kuźma, od początku swej drogi naukowej znacznie mniej przywiązany do rygoryzmu myślowego strukturalistycznej teorii literatury, powracał do hermeneutycznej koncepcji Wilhelma Diltheya, który pojmował biografię jako opis osobowości autora, niepoddający się w pełni racjonalnej wykładni. Kuźma także uznawał, że nie ma rady - realnego autora nie można oddzielić od utworu. „I w tej mierze nie pozostaje nam nic innego, jak pozostać przy propozycjach Diltheya: transponować własną jaźń na zakodowaną ekspresję życia"12. Nie jest to jednak pozytywna oferta dla biografistyki. Kuźma sądził, że skoro trudno jej zachować obiektywizm w selekcji i hierarchizacji faktów życiowych, najlepiej byłoby rejestrować je w formie kalendarium, kroniki czy podobnie sprawozdawczych gatunkach. Ostatecznie trzej przywołani tutaj badacze spotykali się w podobnej konkluzji, że punktem wyjścia i uzasadnieniem dla naukowej biografii powinna być literatura.

Zupełnie inny punkt widzenia pojawiał się z drugiej strony - w refleksji pisarskiej dotyczącej znaczenia biografii. Julia Hartwig, poetka, a także autorka znakomitych biografii Apollinaire'a i Nervala, którą zamierzam dalej powołać na świadka w procesie obrony - nazwijmy ją tak - hermeneutycznej biografistyki, w jednym z felietonów pisała:

Surowe oddzielanie biografii autora od jego dzieła wydawało mi się zawsze czymś paradoksalnym. Jako gorliwą od lat czytelniczkę literatury, zawsze interesowało mnie, jaki też był w życiu autor tej pięknej fikcji, która mnie zachwyciła, lub wiersza, który mnie poruszył.

[...] niezależnie od postępów strukturalizmu, tak zwany zwyczajny czytelnik bynajmniej od biografistyki się nie odwrócił, wynika ona bowiem z nieposkromionej ciekawości ludzkiej poszukującej wciąż nowych wzorców istnienia. ${ }^{13}$

W wypowiedzi tej biografia ma sens parenetyczny, a pewnie też aksjologiczny. Chcemy porównać los obcy z własnym, być może też pośrednio, wirtualnie wejść w nurt cudzego życia jako bytu alternatywnego, który nigdy nie był i nie będzie nam bezpośrednio dostępny. „Życie zastępcze” czytelnika biografii mieści się jakoś w Diltheyowskiej koncepcji wczucia, rozpoznania jaźni autora. Słowa Julii Hartwig o poszukiwaniu w biografii „nowych

12 E. Kuźma Kategoria biografii, w: Biografia - geografia..., S. 115.

13 J. Hartwig Kłopoty z biografiq, w: Pisane przy oknie, Biblioteka "Więzi”, Warszawa 2004, s. 84-85. 
wzorców istnienia" nieoczekiwanie współbrzmią z myślą przedstawiciela niemiłego jej obozu strukturalistów. Oto bowiem Janusz Sławiński, podkreślając znaczenie dla biografistyki kategorii twórczej osobowości, definiuje ją jako „sferę strukturalności przeciwstawną potokowi wydarzeń" i powiada, że takie rozumienie stawia „biografa wobec zadania hermeneutycznego: w tworzywie wszelkich dostępnych manifestacji aktywności osobniczej ma odnaleźć i odczytać zaszyfrowany wzór życia"14.

2.

Na pozór podobnie pojmowano literaturę w romantycznej, a potem w pozytywistycznej formule przetwarzania egzystencjalnych doświadczeń autora w dziele. Zanim doszło do wykształcenia nowego, formalistyczno-strukturalistycznego paradygmatu opisywania relacji osobowych w tekście, istotne modyfikacje romantycznej koncepcji autora przyniosła krytyka personalistyczna i młodopolski ekspresywizm. Jak dowodził Michał Głowiński, w krytyce młodopolskiej zasadniczą rolę odgrywała dyrektywa empatii i utożsamienia ${ }^{15}$. Zdaniem badacza mimo stosunkowo słabej recepcji (niemal nieobecności) pism Wilhelma Diltheya i w zasadzie niezależnie od jego teorii, kształtuje się w okresie Młodej Polski wyraźna krytycznoliteracka tendencja, którą Głowiński nazywa (za Günterem Scholzem) hermeneutyką techniczną. Pojmuje ją jako praktykę interpretacyjną, wyjaśniającą pozajęzykowe formy symboliczne. „Tę epokę charakteryzuje w Polsce ogólnie diltheizm avant la lettre", czytamy w studium Od impresjonizmu do hermeneutykit ${ }^{16}$.

Młodopolski ekspresywizm ujmował związek podmiotu z dziełem jako strukturalną jedność, której odczytanie wymagało „wczucia”. Empatia stała się formą rozumienia. Stanisław Brzozowski pisał: „aby zrozumieć, trzeba przeżyć i wznieść się ponad przeżycie, trzeba przezwyciężyć czyn czynem, wartość wartością"17. Dyrektywa ta wyraźnie nakazuje ruch dwukierunkowy: ku autorowi (i jego dziełu), a następnie od autora i dzieła - w stronę krytycznego, podmiotowego Ja. Dzięki „wzniesieniu się ponad przeżycie” krytyk,

\footnotetext{
14 J. Sławiński Myśli na temat: biografia pisarza..., s. 18 (wyróż. - A.L.)

15 M. Głowiński Ekspresja i empatia. Studia o młodopolskiej krytyce literackiej, Wydawnictwo Literackie, Kraków 1997.

16 Tamże, s. 62-96.

17 Tamże, 96.
} 
mówiący językiem autora (co uwidaczniała częsta obecność mowy pozornie zależnej), mógł zachować własną tożsamość. Porozumienie następowało w owej sferze symbolicznej, ponad dziełem, jako wspólnota ducha.

Michał Głowiński przypominał, że krytyków modernistycznych nie interesowało życie twórcy w takim zakresie, jaki wyznaczała monografistyka pozytywistyczna. Gadamerowska „presupozycja pełni”18 obejmowała wyjaśnianie związku autora z syntetycznie ujmowanymi cechami jego twórczości. „Integralny poeta" miał objawiać się w ulubionej formie portretu literackiego ${ }^{19}$. Modernistyczna kariera tego gatunku, mającego już dość długą tradycję, wiązała się z rozpowszechnieniem personalizmu, stawiającego pisarza w centrum uwagi krytyka. W odróżnieniu od portretu pozytywistycznego (który mimo wszystko przetrwał w piśmiennictwie o charakterze popularnym), chodziło teraz nie o prezentację przebiegu życia, lecz o portret „duchowy”. Głowiński określa go mianem „podstawowej inicjatywy hermeneutycznej”" Wyróżniała się ona ograniczeniem procedury analitycznej, podporządkowywanej jakiejś formule ogólnej, nierzadko metaforycznej, która pełniła funkcję scalającą właściwości dzieła z duchową i osobową konstytucją pisarza.

Kategoria osobowości wielokrotnie zaprzątała uwagę XX-wiecznych filozofów, psychologów i badaczy literatury, spotykających się w przestrzeni interdyscyplinarnej refleksji na temat podmiotu (twórczego) ${ }^{\mathbf{2 1}}$. Jedną z ważniejszych prac w tym zakresie pozostała rozprawa Jana Józefa Lipskiego Osobowość twórcza z 1983 roku, w której podjął on próbę swoistej rehabilitacji biografistyki, próbując zarysować przed nią - zgodnie z postulatami strukturalistów - nowe perspektywy bez zadłużania się w psychologii twórczości. Jednocześnie badacz dostrzegał redukcjonizm strukturalistycznej koncepcji „podmiotu czynności twórczych” i pisał:

Następnym krokiem będzie, jak sądzę, ponowne połączenie pozrywanych więzi łączących twórcę i dzieło, co pozwoli znów widzieć w dziele literackim - na innym już szczeblu świadomości teoretycznej - wytwór określonego człowieka, osobowości ludzkiej, z wieloma stąd płynącymi

Tamże, s. 95

M. Głowiński Portret literacki, w: tegoż Ekspresja i empatia, s. 128-141.

Tamże, s. 140 (podkr. - A.L.)

Szerzej proces ten opisuje Janina Abramowska w wartościowym studium przeglądowym Podmiot autorski - przemiany teorii i praktyki literackiej, w: tejże Rekonstrukcje i konstrukcje. Studia literackie, Poznańskie Studia Polonistyczne, Poznań 2003, s. 155-174. 
implikacjami. Widzę w tym zarówno postulat teoretyczny, jak i ideologiczny [...]. W płaszczyźnie ideologicznej - zależy mi mianowicie, by przywrócić na tym odcinku wagę jednej z dominant światopoglądowych naszego kręgu kulturowego od czasu renesansu: przekonaniu o związku nie tylko fizycznym i genetycznym, lecz głębszym, między twórcą a wytworem, o tym, że twórczość jest w jednej ze swych podstawowych funkcji śladem człowieka, osobowości, indywidualności w historii, jego świadectwem i wyrazem [...]. Jest to jednocześnie postulat przeciwstawienia się humanistyce bez nazwisk, bez osobowości, takim koncepcjom literatury, które gubią ludzką indywidualność. Jestem przeświadczony, że postulaty te są do pogodzenia ze stanem współczesnej humanistyki, w szczególności literaturoznawstwa, wymagają jednak nowych przeformułowań, które nie ignorowałyby przy okazji niczego, co jest teoretyczną zdobyczą ery antypsychologizmu i antybiografizmu; jest ona, niestety, zarazem erą odindywidualizowania historii literatury, a formułując ostrzej: jej dehumanizacji. ${ }^{22}$

Słowa te, układające się w wyraźny manifest, padły w przededniu ekspansji poststrukturalizmu, który wlał się do polskiej humanistyki nieco spóźnioną, lecz mocno spiętrzoną falą. Będzie on proklamował „śmierć autora”, potem przyniesie połowiczne próby ocalenia go za pomocą koncepcji „sygnatury”, w jeszcze innych teoriach ożyje jako podmiotowość „śladowa”.

Julia Hartwig, w wykładzie zaprezentowanym podczas uroczystości nadania jej godności doktora honoris causa przez Uniwersytet im. Adama Mickiewicza, mówiła: „Poezję trudno oderwać od poety, od jego osoby, bez względu na to, ile tak zwanego «lirycznego ja» przemawia do nas z wierszy bezpośrednio. Można by nawet powiedzieć, że wiersze pisze się nie piórem, ale osobowością. Im osobowość jest bogatsza, tym ciekawsze wiersze"23. Wedle Jana Lipskiego kategoria osobowości może zostać wyabstrahowana z samego dzieła. Obejmuje ona aspekty takie jak wyobraźnia twórcza, kształtująca podmiotowy sposób zmysłowej percepcji świata (w tym widzenie i przeżywanie czasu oraz ruchu), preferencje i fobie tematyczne, a przede wszystkim - dające się wydobyć z analizy możliwie dużego korpusu tekstów

J.J. Lipski Osobowość twórcza, w: Problemy teorii literatury, Seria 3, Prace z lat 1975-1984, wyb. H. Markiewicz, Ossolineum, Wrocław 1988, s. 384-385. 
mentalność, światopogląd i właściwości charakterologiczne. Na tym jednak nie koniec. Lipski bowiem, wbrew strukturalistycznym dogmatom, stwierdzał bardzo dobitnie: „nie ma, jak sądzę, takich badań historycznoliterackich, które mogłyby naprawdę ograniczyć się i odnieść wyłącznie do tekstu"24. Upominając się o „transcendentny” kontekst, w którym literatura funkcjonuje, badacz - uznając dzieło za podstawowe źródło wiedzy o autorze - otwierał też przestrzeń dla szerszego rozumienia dokumentu biograficznego:

Pisarz, konkretna osoba, integralna, lecz złożona i wieloaspektowa osobowość, występuje w rozmaitych rolach społecznych, a żadna z nich nie jest bez znaczenia dla użytku, który zrobią badacze jego osobowości z materiału dostarczonego przez obserwację jego zachowań i interpretację jego wytworów. ${ }^{25}$

Przyznam, że nie bez interesu prywatnego cytuję słowa Jana Lipskiego, szukając w nich uzasadnienia dla własnego sposobu pojmowania biografistyki, o którym zamierzam napisać dalej. W przytoczonym fragmencie chcę podkreślić hierarchię elementów materiału zbieranego przez „badacza osobowości" twórczej. Lipski wymienia (być może zresztą przypadkowo) najpierw obserwację zachowań pisarza, a potem dopiero interpretację jego wytworów. Podział ten pozwala schematycznie wyróżnić dwa bieguny, między którymi lokują się różne odmiany biografistyki. Jeden tworzy życie pisarza, drugi twórczość. Formy „przyciągane” przez pierwszy biegun łatwiej poddają się beletryzacji, z kolei teksty zorientowane na twórczość sprzyjają ujawnieniu hermeneutycznej postawy biografa i tym samym lokują się bliżej Gadamerowskiej „rozmowy”. Aby poprzeć ten nieskomplikowany koncept typologiczny przykładami z własnej praktyki, mogę wskazać napisaną przed laty książeczkę pt. Wisława Szymborska ${ }^{\mathbf{2 6}}$, w której życiu poetki poświęciłam niewielki fragment, skupiając się dalej na wyjaśnianiu tekstów, prowadzącym do hipotezy całościowego sensu twórczości. Z kolei w biografii Julia Hartwig. Wdzięczność, której tytuł również ma być kluczem do całości (obejmującej zarówno życie, jak i twórczość) interpretacje utworów nie są dominujące i nierzadko ustępują narracji o kolejach losu poetki. Różnice te wynikają

\footnotetext{
24 J.J. Lipski Osobowość twórcza, s. 381.

25 Tamże, s. 387.

26 A. Legeżyńska Wisława Szymborska, Wydawnictwo Rebis, Poznań 1996.
} 
z różnych koncepcji wydawniczych obu książek, które miały być kierowane do nieco odmiennych grup odbiorców i podporządkowane innej regule konstrukcyjnej. Niewykluczone, że dziś napisałabym je inaczej. I niewykluczone, że mimo wszystko pozostałaby w nich nadal widoczna autorska sygnatura, implikująca mój osobisty światopogląd i sposób czytania poezji.

W biografii chodzi o prezentację osobowości twórcy, któremu nieodłącznie towarzyszy cień biografa. Twórca jest bohaterem, postacią na scenie opowieści, ale to biograf ustawia dekoracje i udziela głosu postaciom. Narracyjna osobowość autora biografii ma w sobie tym więcej cech tyranii, im bliżej beletrystyki. Być może słusznie Erazm Kuźma w kronikarskich formach upatrywał dla biografa szansy zachowania neutralności. Tego rodzaju prace są jednak zwykle podejmowane przez wieloosobowe zespoły autorów, zaś w ostatnich dekadach widać wyraźnie, że narratywizacja form biograficznych bardzo się rozpowszechnia. Powieściowe biografie łatwiej wchodzą w obieg rynkowy, a mogą być także pisane przez badaczy profesjonalnych (jak proza Renaty Lis czy formy sylwiczne Jarosława Marka Rymkiewicza). Biografistyka naukowa szuka sposobu, by poszerzyć rejestr form dokumentarnych. Udaną próbą jest mikrobiografika prasowa, proponowana przez Krzysztofa Stępniaka w jego dwóch książkach o Sienkiewiczu²7.

\section{3.}

Ryszard Nycz w klasycznym już studium Osoba w nowoczesnej literaturze: ślady obecności porządkuje problemy, o których tutaj częściowo już była mowa, nazywając je procesem „ucieczki od osobowości” ${ }^{28}$. Przypomina, że „pytając o osobę, pytamy w praktyce przede wszystkim o jej historycznie usankcjonowane atrybucje oraz kulturowo uznawane sposoby identyfikacji"29. Dalej zaś charakteryzuje kategorię autora (i podmiotu), uwzględniając jego relacje ze światem zewnętrznym i medium języka. Proponuje rozróżnienie pozycji autora przedmodernistycznego, "trwale ukonstytuowanego" i stojącego naprzeciw „podobnie trwale ukonstytuowanej rzeczywistości”, oraz autora modernistycznego, tracącego substancjalność i stającego się „częścią

27 Zob. K. Stępnik Henryk Sienkiewicz. Studia z mikrobiografiki prasowej, Wydawnictwo UMCS, Lublin 2016 oraz Sienkiewicz globalny, Wydawnictwo UMCS, Lublin 2017.

R. Nycz Literatura jako trop rzeczywistości. Poetyka epifanii w nowoczesnej literaturze polskiej, Universitas, Kraków 2001, s. 50. 
procesu, który opisuje"30. Najważniejsza jest jednak konkluzja, że literackie ślady osobowej obecności stają się jedynie „zapisem tropicznym”, tropem performatywnym, „który nie daje się oddzielić bez szkody od empirycznej autorskiej osobowości, bo pełni wobec niej rolę współkonstytuującą"31. Ustalenia te mają znaczenie dla typologii świadectw biograficznych i, w konsekwencji, dla sposobu interpretacji biograficznej.

Materiały dostępne dla autora biografii są tekstami w większości językowymi, choć niektóre mogą mieć charakter przekazów ikonicznych (fotografie, portrety), zapisów fonograficznych czy filmowych. Wśród świadectw pisanych pojawiają się urzędowe dokumenty, epistolografia, dzienniki i pamiętniki, zapiski użytkowe (kalendarze, notatki), wywiady, okazjonalne wypowiedzi, autokomentarze, wreszcie, wszelkie utwory literackie, także bruliony i teksty nieliterackie (np. krytyczne). Osobowość twórcza emanuje z nich w różnym stopniu jawności. Oprócz wymienionych źródeł biograf może mieć do dyspozycji świadectwa zapośredniczone (cudze wspomnienia, opinie, charakterystyki) i empiryczne - doświadczeniowe, zebrane w bezpośrednich i osobistych kontaktach z twórcą. To sytuacja szczególna, tyleż fortunna, co niebezpieczna.

Pisząc książkę o Julii Hartwig na podstawie niemal wszystkich wymienionych rodzajów świadectw biograficznych, miałam dojmujące poczucie jej fizycznej obecności (gdy pisałam, poetka jeszcze żyła, gdy złożyłam maszynopis do wydawnictwa, zmarła dwa tygodnie później). Pamięć realnej osoby hamowała wyobraźnię. Znałam Julię Hartwig z bezpośrednich, choć nielicznych kontaktów, także z naszej korespondencji i rozmów telefonicznych. Przede wszystkim jednak znałam ją z wierszy, eseistyki, felietonów, listów, wywiadów. Medialny wizerunek poetki, starannie przez nią samą kontrolowany, pozostawał w zgodzie z moim osobistym doświadczeniem, wyniesionym z rozmów i wizyt. Wiedziałam sporo o jej życiu, ale pozostawała jeszcze większa sfera niewiedzy. Założyłam, że napiszę biografię samodzielnie, nie weryfikując dokumentów we współpracy z poetką (której zamierzałam ujawnić swą pracę dopiero po wydrukowaniu). W rezultacie stworzyłam biografię wyobrażoną na podstawie materiałów różnego typu, od tekstów dokumentarnych przez autobiograficzne, aż do literackich, a także na podstawie zapamiętanych doświadczeń osobistego kontaktu z Julią Hartwig.

Tamże, s. 59.

Tamże, s. 86-87. 
Podglądałam jej warsztat jako autorki wysoko cenionej przez krytykę prozy biograficznej: Apollinaire (1962) i Nerval (1972). Obie książki nie mają przypisów, bibliografii ani żadnych cech naukowej monografii, mimo że powstały na podstawie tysięcy dokumentów i rozmów. Poetka posłużyła się narracją powieściową, od pierwszych stron wprowadzając czytelnika w świat na wpół fikcjonalny:

Kiedy młody wychowanek szkoły jezuickiej i skromny adept literacki, André Billy, wszedł do podziemia kawiarni „Soleil d’Or” położonej na rogu bulwaru Saint-Michel, w najbliższym sąsiedztwie Sekwany, było tam ciemno od tytoniowego dymu i tak tłoczno, że z trudem znalazł miejsce przy stoliku zajętym już przez dwóch młodych ludzi o rozwichrzonym, zdecydowanie poetyckim wyglądzie. ${ }^{32}$

Nietrudno w tym fragmencie usłyszeć typowy dla twórczości Julii Hartwig rytm zdania, bardzo rozwiniętego, a jednak klarownego. Składnia, zdanie - o którym poetka w innym miejscu powie, że jest głównym modułem wiersza - określają narrację, prowadzoną płynnie, lecz niespiesznie. Istotne jest skupienie uwagi na detalu (materialnym i topograficznym), sprzyjającym obrazowości przedstawienia. Wśród komentarzy do Apollinaire'a zwraca uwagę opinia Jarosława Iwaszkiewicza, nazywającego książkę „portretem”. Technika portretowa mnie także wydała się najbardziej naturalna, choć oczywiście mam świadomość proporcji - Wdzięczność nie jest przesycona fikcją literacką, nie jest też formą powieściową. Składa się z szeregu chronologicznie uporządkowanych portretów jednej osobowości. Początek brzmi tak:

Niewysoka, wyprostowana sylwetka. Skupione, uważne spojrzenie. Niezmienne uczesanie z charakterystyczną, stylową koroną warkocza wokół głowy. Zawsze ten sam sznureczek pereł wokół szyi i drobne, także perłowe kolczyki. Mówi spokojnie, starannie, precyzyjnie dobierając słowa... ${ }^{33}$

Nie jest to obraz Julii Hartwig wymyślony, lecz kiedyś w rzeczywistości zobaczony. Ale przecież musiało zdarzać się, że nie miała na sobie sznureczka pereł albo że nie mówiła spokojnie... Powraca pytanie o wspominaną przez Franaszka „uczciwość” biografii. Czy jest możliwa i w jakim sensie? Jeśli

32 J. Hartwig Apollinaire, Świat Książki, Warszawa 1972, s. 17.

A. Legeżyńska Poezja uosobiona, w: Julia Hartwig. Wdzięczność, s. 11. 
miałaby ją gwarantować prawda dokumentów, to łatwo taki sąd podważyć, odwołując się do nowych metodologii z zakresu historiografii. Być może chodzi o uczciwość pojmowaną jako zgodność opisu z doświadczeniem biografa?

Mieści się w nim zarówno przetwarzanie dokumentów, jak też empatia, o której już była mowa. Ale także praca wyobraźni. Wydaje mi się, że pisanie biografii - niezależnie od wariantu gatunkowego - przede wszystkim jest (posługując się formułą Kazimierza Wyki, mówiącego tak o poezji) rzeczą wyobraźni, potem empatii. Dlatego właśnie swoją książkę o Julii Hartwig nazywam biografią wyobrażoną. Myślę, że forma ta mieści się w praktyce badawczej, którą Ryszard Nycz określa jako literaturoznawstwo osobiste ${ }^{34}$. Ma ono, czego dowodzi z kolei Michał Januszkiewicz, wymiar hermeneutyczny, gdyż doświadczenie tworzy podstawowy horyzont rozumienia tekstów:

Można tu nawet zaproponować inną wersję hermeneutycznego koła: w takim tylko stopniu, w jakim rozumiemy samych siebie, możemy rozumieć tekst (tylko wtedy on do nas przemówi); i na odwrót: na tyle, na ile rozumiemy tekst, możliwe jest pogłębianie i poszerzanie własnego horyzontu rozumiejącego bycia-w-świecie. ${ }^{35}$

Aporetyczna sytuacja pisania cudzej biografii jest wyzwaniem i wezwaniem, by nie przekroczyć granicy subiektywności, lecz zarazem ocalić jednostkowość doświadczenia spotkania z Innym. Dla biografa początkiem drogi umożliwiającej takie spotkanie jest fascynacja osobowością pisarza. Wyobraźnia, empatia i fascynacja tworzą hermeneutyczną ramę modalną tekstu biograficznego, którego celem - oprócz zysku pragmatycznego - jest utrwalenie jednostkowości czyjegoś losu. Podobnie Czesław Miłosz w wierszu Medytacja pisał:

[...]

Wystarczy mocno i wytrwale zastanawiać się nad jednym życiem,

Pewnej kobiety na przykład, jak teraz robię,

A ukazuje się wielkość tych jakże słabych istot,

Które umieją być prawe i dzielne, cierpliwe aż do końca. ${ }^{36}$

Zob. R. Nycz Tekstowe doświadczenia, "Teksty Drugie” 2010 nr 1/2, s. 12. M. Januszkiewicz Być i rozumieć. Rozprawy i szkice z humanistyki hermeneutycznej, Fundacja „Instytut Myśli Józefa Tischnera”, Kraków 2017, s. 110. 
Nie jest to wiersz o Juli Hartwig. Ale dobrze współbrzmi z moją intencją biograficzną i kryje odpowiedź na pytanie, dlaczego swoją książkę o poetce nazwałam Wdzięczność.

\section{Abstract}

\section{Anna Legeżyńska}

ADAM MICKIEWICZ UNIVERSITY (POZNAŃ)

"Just to Delve into One Life...": Life Writing as a Hermeneutic Challenge

There is more than a formal difference between autobiography and biography understood as a text or process of describing another person's life. Biography has a distinct modal framework that depends on three factors: the biographer's fascination, empathy and imagination. These three, Legeżyńska argues, have a hermeneutic role, for they determine how the biographer interprets not just facts but the whole meaning of the subject's life and work. Legeżyńska recalls how formalist and structuralist theories attempted to discredit the notion of (the real author's) personality, then reviews representations of biography in personalism and in modernist aesthetic of portraiture - representations that anticipate her own concept of life writing. Her own experience of writing a biography (of the poet Julia Hartwig) is positioned in the movement of what Ryszard Nycz has called "personal literary scholarship". She proposes the notion of "imagined biography" to describe her own preferred convention of describing a creative personality.

\section{Keywords}

hermeneutic situation, creative personality, biographical intention, imagined biography 